\title{
阿武魾隆起準平原北部の地形発達 ${ }^{*}$
}

\section{中 村 晋 男}

\section{1 まえがき}

呵武险高原の地形については，上として中辣

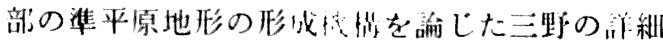

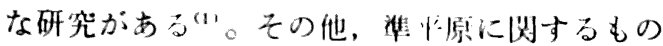

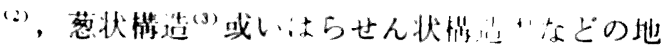
形模遗に阅与るものなど，いくつかの文献があ

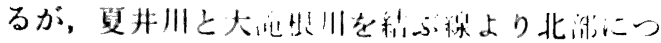

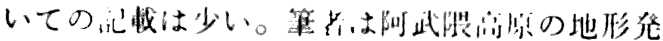

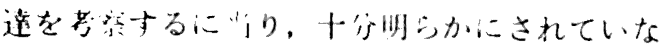
いこの北涑地域の地形的特改をまず把握するこ とが必要と考え，1958年夏以降瑚值を行つた。

本地域には，四から大体1/3のとこうに分水界

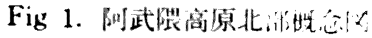

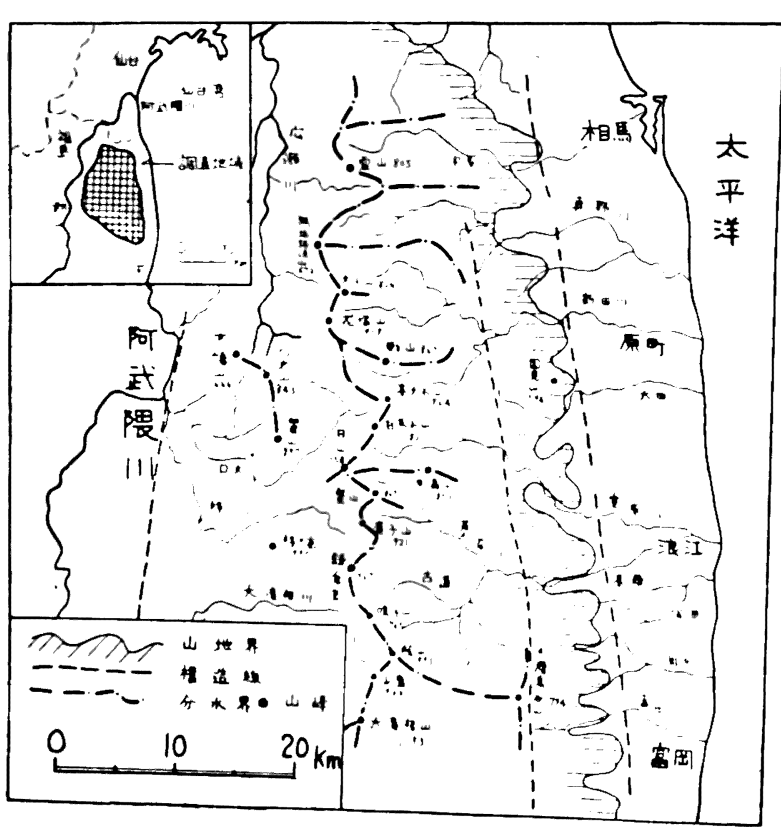

がほぼ南北に起ているが，分水界と云つても 急骖な托相は少く，孤立した山峰が点在し，そ の间が低い纱によつて連なつているに過ぎな い。ここから東流する河川は，い与れも40-50 $\mathrm{km}$ の流路をもつてほほ平个配列している。 往流寸るものはいずれも阿武隈川の支流で，流 路のおさは 20-30 km，方向は平行でなく公頪 川は本地城の北西秝の满造線に沿5緃谷で淔線 状に北流し，口太川は格子状流路で，方向をは ば田に 3 度も変えている。移川，大潼根川は 北阮に流れて阿武䯈川に注いでいる。

呵武郎山地を桠成する地質 ${ }^{(3)}$ は，大部分が古 生代，中生代に具人した花阙岩類で，東緑に近 く, 粘板岩・砂望・石炏岩等からなる古生 㬝，中生層が発達している。第三紀㬝は常

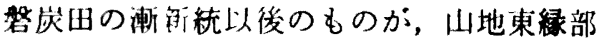
に紼長く分布する。山地東縁を限る大断層 采 (爻染構造線) は，上部中新統多賀層群 堆詣㨁前にた形成されもので，その後も断 絖的に活動したことが知られている。また

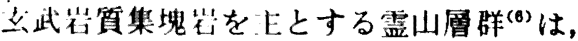
留山附近を中心に阿武郎高原最北部に分布 する、第四糺層は洪稍層の郡山㬝，塚原貝 層がそれぞれい地よりはずれて西と東に分 们する他，山地内部の小盆地に沖䅡層が見 られるのみである。

わが国に打ける準平原に関する地形学的 研究は割合多く,それらは, 梠平原地形一般 ${ }^{(7)}$, 準平原化作用 ${ }^{(8)}$, 準平愿の種類 ${ }^{(8)}$ ，地形

*東北地理学会1960年悸学衙大会に発表

(1) 三野与吉：地形原唃（1942）はか，间著者に上る交献多数

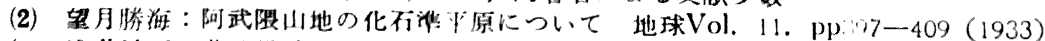

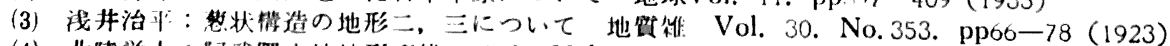

(4) 北陵学人：阿武变川地地形案描 地球 Vol. 8. No. 5. pp344-354 (1930)

(5) 半沢正四郎：日本地方地算誌束北地方 (1954)

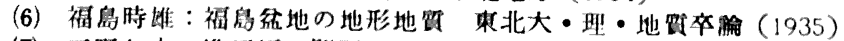

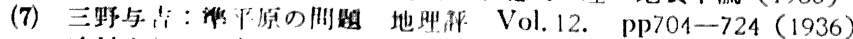

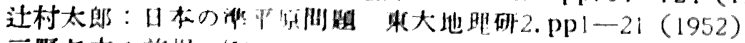

(8) 三野与吉：前指 (1) 
計測的方法(10)などを扱つている。外国ではドイ ッで研究が進んでおり, 最近, Louis ${ }^{(1)}$, Hempel $^{(12)}$, Neef ${ }^{(13)}$, Budel $^{(14)}$ などの文献が目立つ ている。

小論をまとめるに当つては，元東北大学教授 富田芳郎先生並びに東北大学地理学数空主任教 授能登志雄先生汇種々適切な御指導を仰ぎ，ま た同しく藤原健葴先生には䅂始助言上鞭撻を頂 いた。ここに深く感謝の意を表するものであ る。

2 侵蝕平坦面の分布

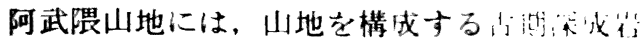
類及び一部:発達する古生骨, 中生憎を切つて 侵蝕平坦面が度く発達している。纱面 Fig-2 及び現地での観察から大きく3つに分けウう。 これを高位のものから，I面、士面，面と呼ふ。

(a) I 面 恶高800-1000m)

本山地では次に述べる慓高 $600 \mathrm{~m}$ 前㣪の平坦 面（I 面）の上に孤立峰が散在しており，它 らの山頂高度はほぼ一定し、しばしは平頂面が 残つている（五十人山883m, 戦山863m, 日山 $1058 \mathrm{~m}$ 等)。全体として中央部に分布するものが 高く, 周辺に行くに従つて高度を減している。

I面はこれらの山㛔の等高平坦面を連ねたも ので，一種の仮想準平原面である。1面を山頂 に持つ山峰の周囲は，極めて平消な科面をなし て】面に繶き，開析谷は㱠んと発墶していない （高太石山 $864 \mathrm{~m}$, 白馬石山821 m, 大火山826m, 五十人山, 口太山843m, 篦川1897m等)。
また，山峰相互の間は，㕕く開いた老年谷を 呈し，上流部に扣いても幻配は極めて緩い。この ことは、これらの河谷がI面をこれ以上開析し 解体する力を持っていないことを示し，山峰斜 面が平衡状態 (平衡斜面形) のまま保たれてい

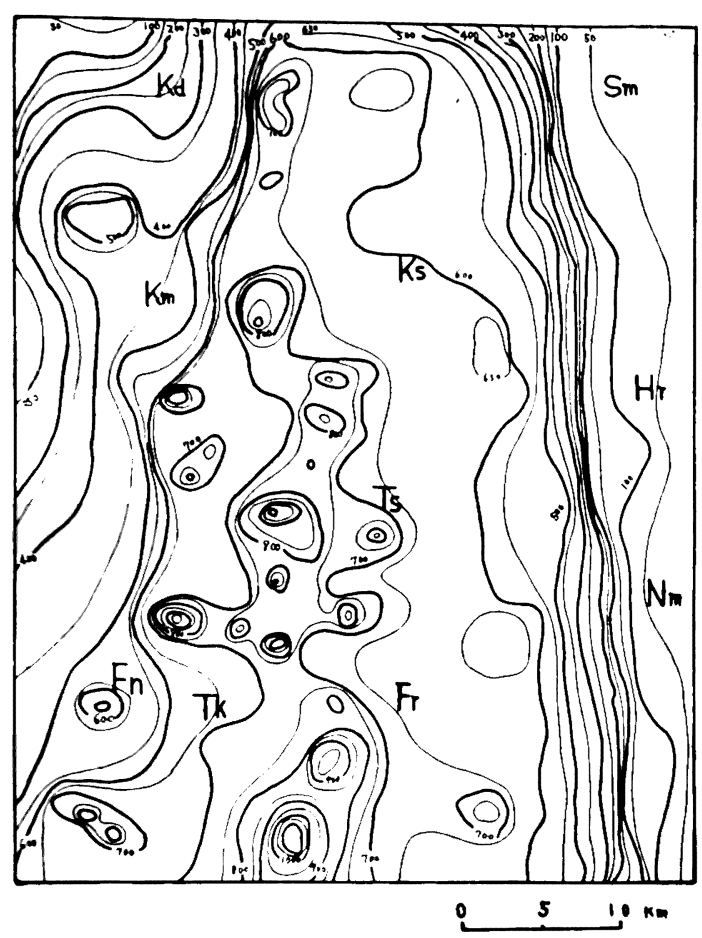

Fig 2. U\%:|iil

\begin{tabular}{|c|c|c|}
\hline $\mathrm{Kd}$ : 扯 & $\alpha$ & $\mathrm{Sm}: H 11$ \\
\hline $\mathrm{Km}: \|$ & lis. & Ki : \\
\hline Fn : 船 & i & $\mathrm{Hr}: \mid 6 \mathrm{~s}$ \\
\hline$T k$ : i & $\dddot{\dddot{x}}$. & Ts : 津 \\
\hline $\mathrm{Fr}:$ 古 & 洋 & $\mathrm{Xm}$ : 浪 \\
\hline
\end{tabular}

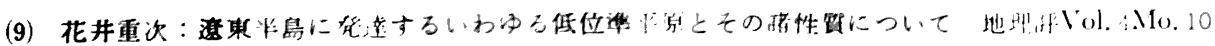
pp927-9: (1928)

畐田方郎: 海南節の地形学的浬题 地理泙 Vol. 20. pp 71-84 (1944)

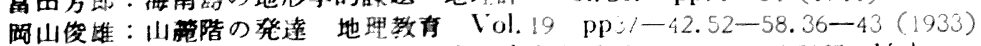

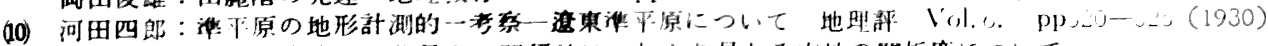

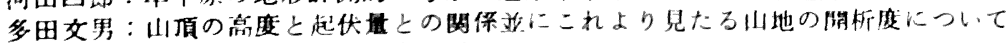

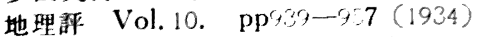

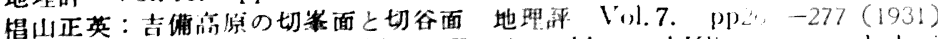

(11) Louis, H. : Rumpfflächenproblem, Erosionzyklus und Klimageomorphologice. Geomorph. Stud, s. 9-26 (1957)

(12) Hempel, L : Flächenformen und Flächenbildung in der Stufenlandschaft. Beobachtungenaus Deutschland und Grossbritanien. Peterm. Geogr. Mitt. Bd. 101.s. 178-184 (1957)

13. Neef, E. : Zur Genese des Formenbildes der Rumpfgebirge. Peterm. Geogr. Milt. Bd. 99. s. 183-192 (1955)

(44) Büdel, J. : Reliefgenerationen und plio-pleistozäner Klimawandel in Hoggar-Gebirge (Zentral-Sahara). Erdk. Bd. \%. s. 100-115 (1955) 


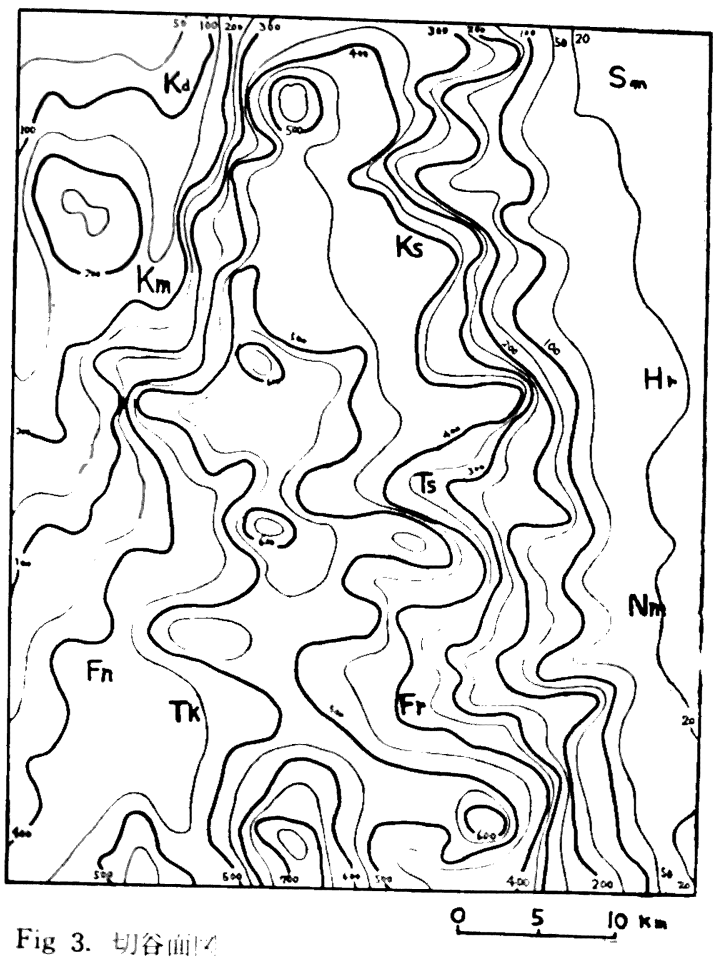

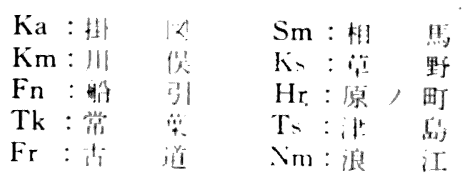

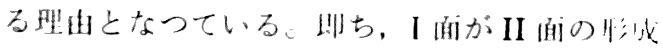

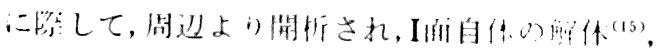

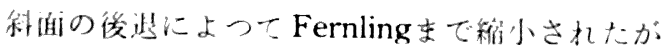

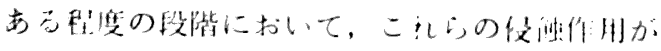

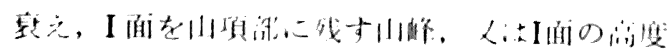

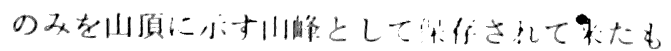
のでサろ 5 。

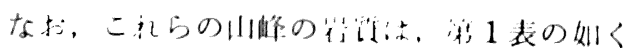

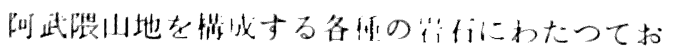

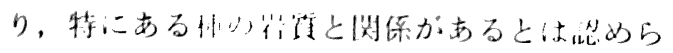
れない。

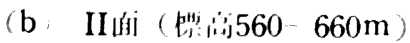

II百は、约们のト位にこれを取り明もよ5に。 山能陹として笑道したものと思われ，この地域

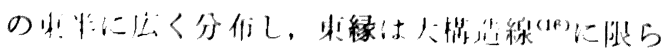

れている。 露山附近で は, 霊山層 群の下位の 位整合面 (660 $\mathrm{m} \pm$ ) がこれであ り(17), その

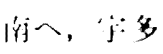
川上流补及 びム瀨川の 一文流を隔 $\tau \tau$, 無拓 路牥川附近の $620 \mathrm{~m}$ の平坦面に続き，来へは宇 タ川，真野川，新田川などの河間地をなす平坦 面 $(600-560 \mathrm{~m})$ に絖く。

この涌は分水界附近では, 残丘（I 面）の山

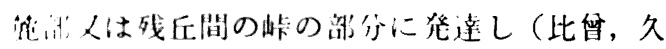

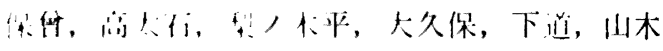

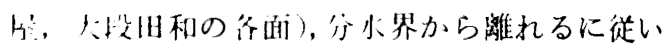
河間后陵の顶涪支なして分们与る（国見山，八

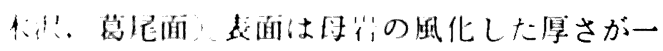

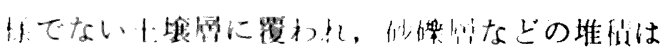
增川附近陷いて全く罗られず，從つてこれは

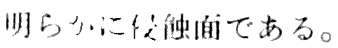

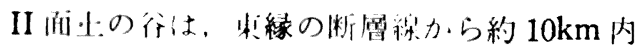
侧まてはV势谷を的してI面を激しく開析して いるが,そいより内側の中流洲以上の地域では 公㖶り褑い,成いた谷であり，时らかに下流部 とは買つた，古いcycle に属すものと婜われる (Fig-5)。

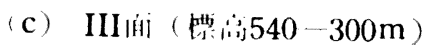

この面の形柋は一般に分小肾の米( k平洋侧) と邽(阿武隈河行倒) 上で若卜異つている。前

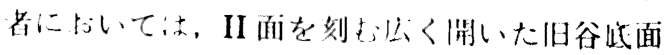

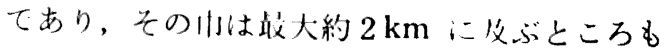

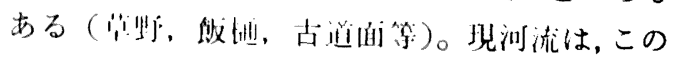
㖇をせいぜい 5 ～ 6 m 刻んでいるに過ぎない。

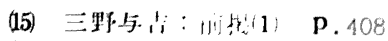

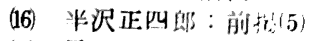

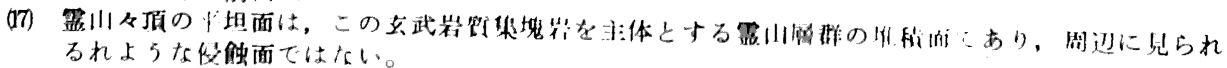


Eig 5. 河床維断面曲線

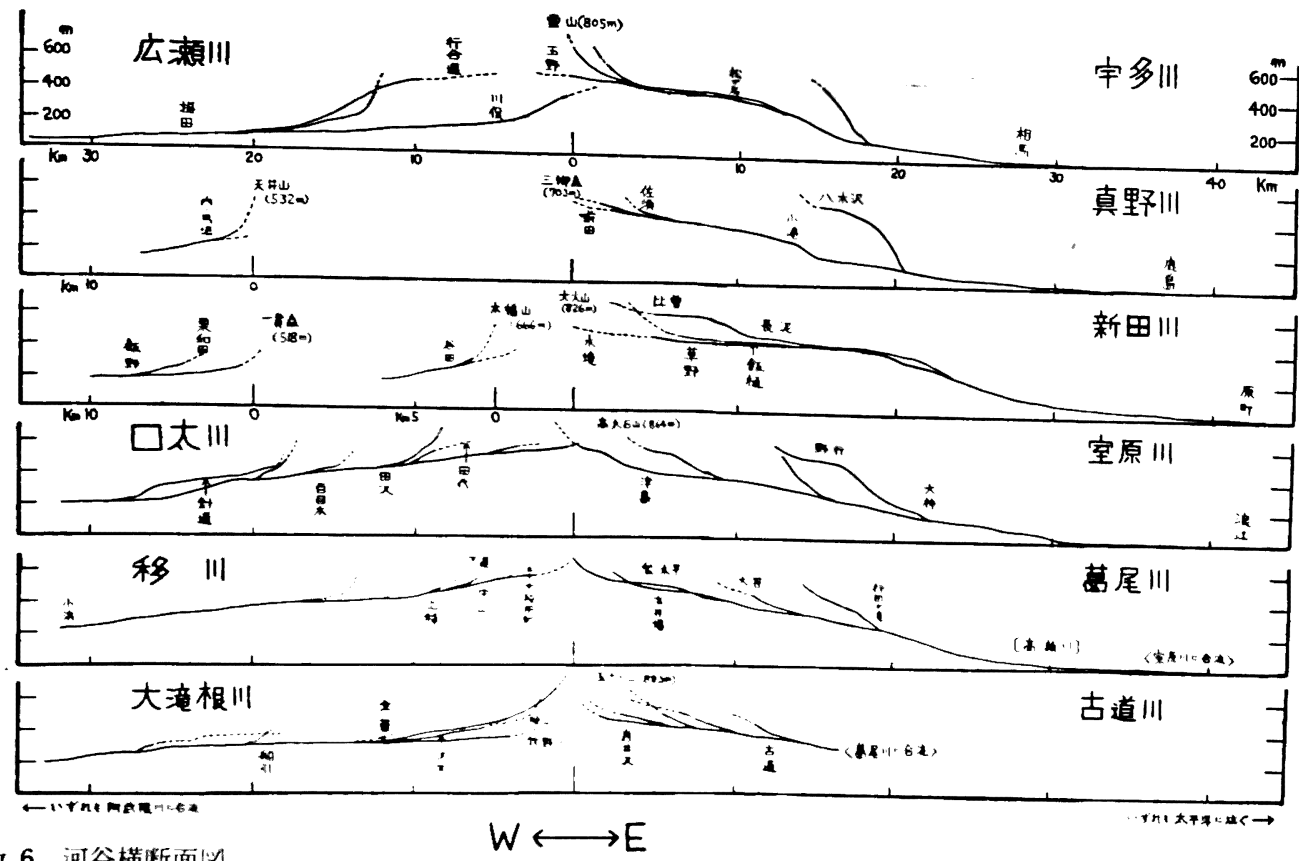

Fig 6. 河谷橫断面闭

面の表面は，II 面と同朕，然岩の風化による紧

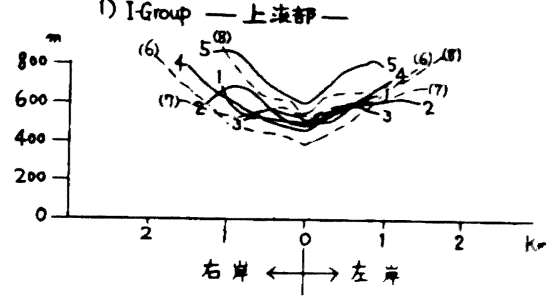

2) II-Group 一中渗部 (1)-

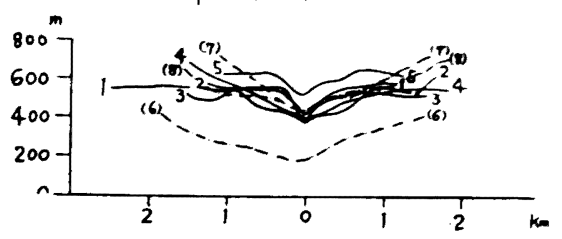

さ0. $5 \sim 1.5 \mathrm{~m}$ 程度の土钲に覆われている（露䫓 が少く，また風化の下限が不明膜なため資料と

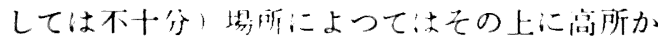

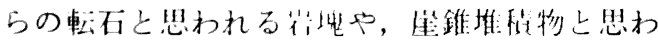
放る angular な啋（任数 $\mathrm{cm} \sim 10$ 数 $\mathrm{cm}$ ) が見ら

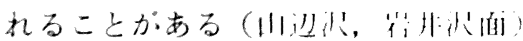

III面形成の状帒を小标ものとして，特微的な

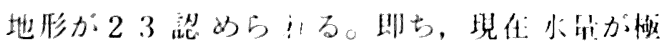

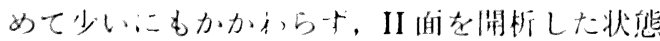

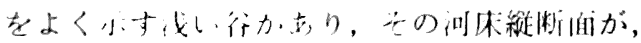

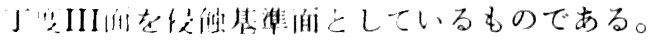

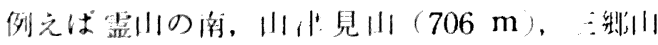

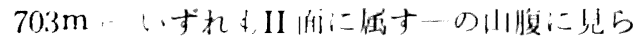

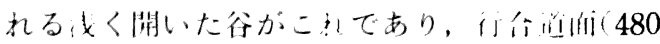
m，III面）に消らかに秒いている(Fig-7)。また

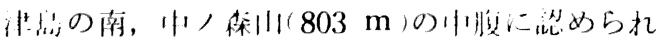

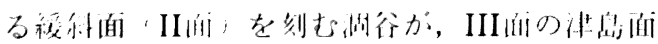

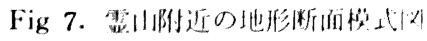
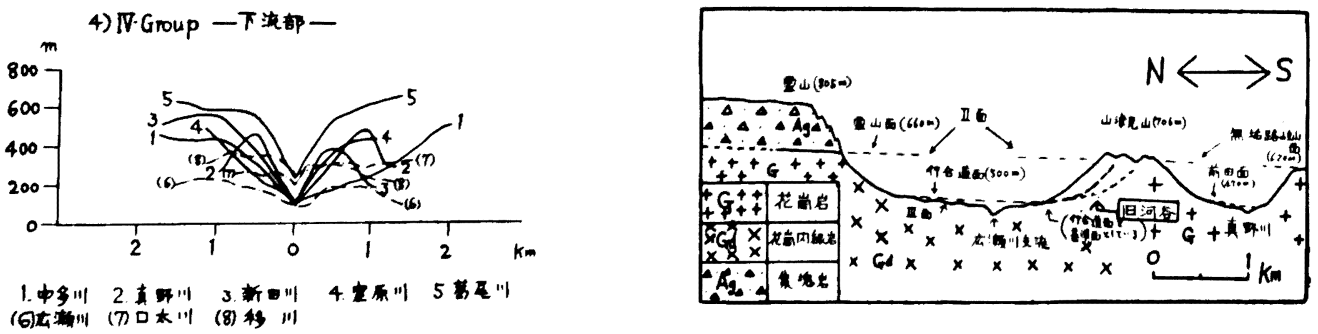
に州视している。これらの行が II而の中に食い 込んでIII面を形成したものであり，III面の性質 がここにふさされている。

II面上III面上の問は大体 smooth に濑移して いるが，斜面の、緗な形態や堆松物の状帒なと はなお今後の䦭題である。

阿武险河谷倒のIII面: II面の周迅から西方

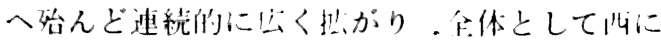

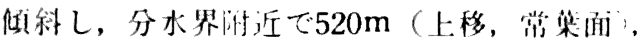
阿武隈川附近で $400 \mathrm{~m}$ 以下（百目位，剑道，紧

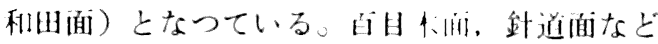
法, 口太川その他の叮武掼川の文流に溯析され て河间地に等向の平顶质陵として战 つている。なお，公瀨川流域では， III面か上，下の 2 坄に分けられ，鬲 位の松力紫，䒺姆，捺野などの面法

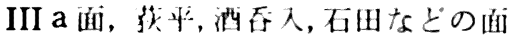
法IIIb面である（第1表）。

III 面がよく発達している人地域

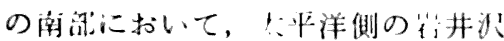
面上阿武险河谷側の沢又面とは，其:

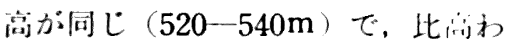
ずか60mの虾でつながつている。

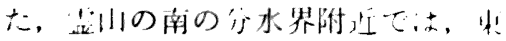
侧の行合道面が幽側の行目沢面汇つ ながる。徒つて本地域の南北を通し て、束西の川I白加对此される。

3 谷形及びこ!と侵蚛半坦佰と の闵保

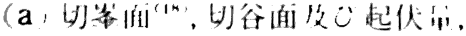

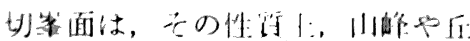
陵の頂部をなす的と II 百について

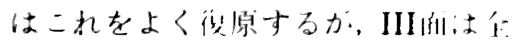
く指摘できない。これに片して，切 谷面からは, 行の华洼の1:明滕な分 水界附近を除けは，六平洋側の各叫

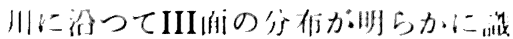
别できる。切行面で等的粽の密な佔 所は, 後述の河目料泊自の明膫な Knick Pointとよ?・楸する。
话，1放触分坦面の分数

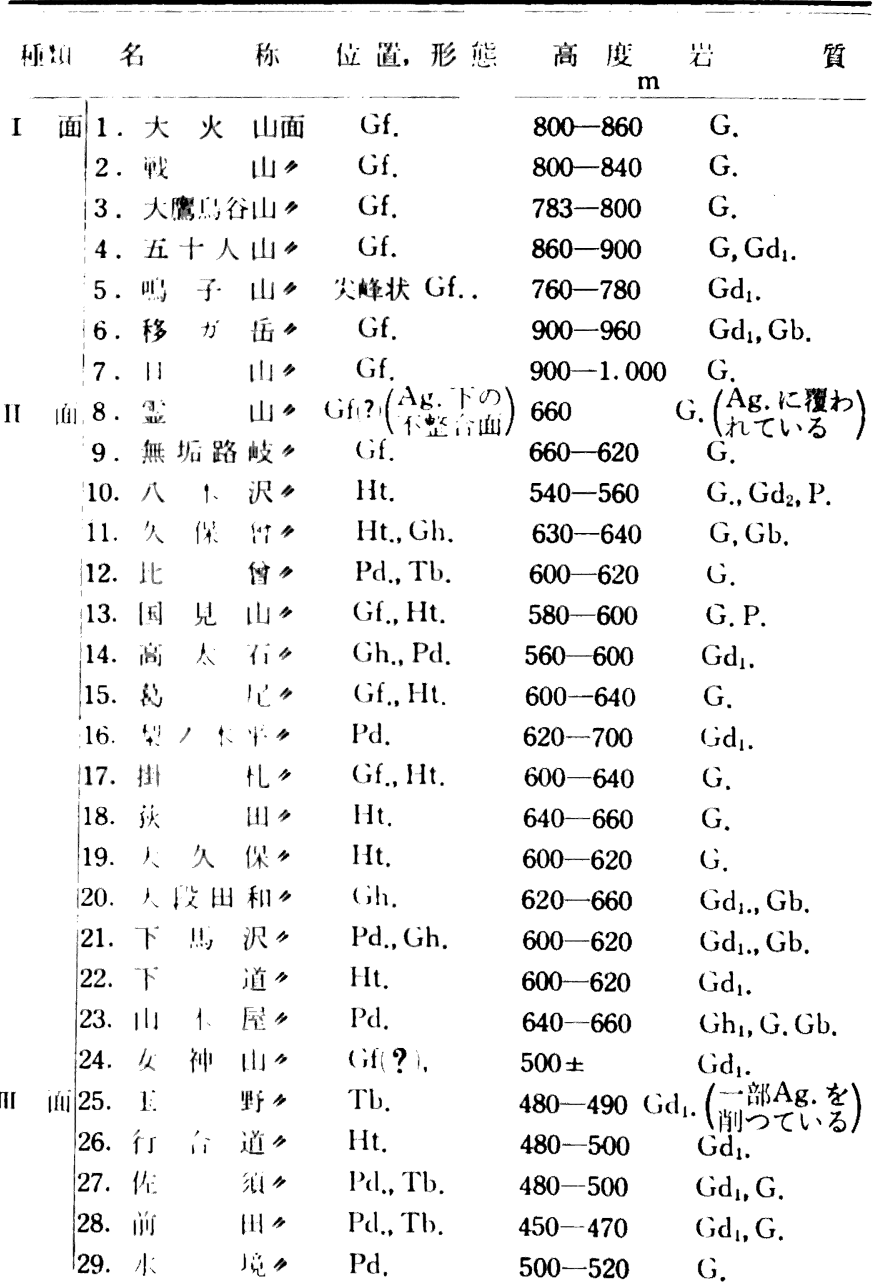

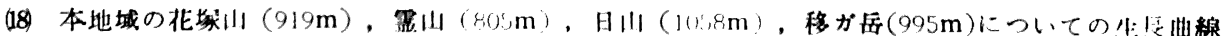

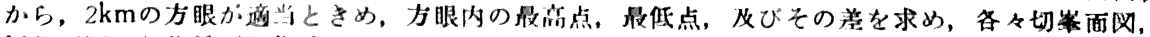
切谷面肉, 起伏地成作成した。

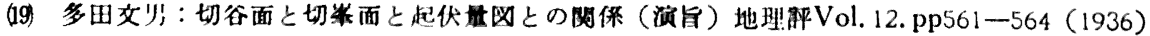




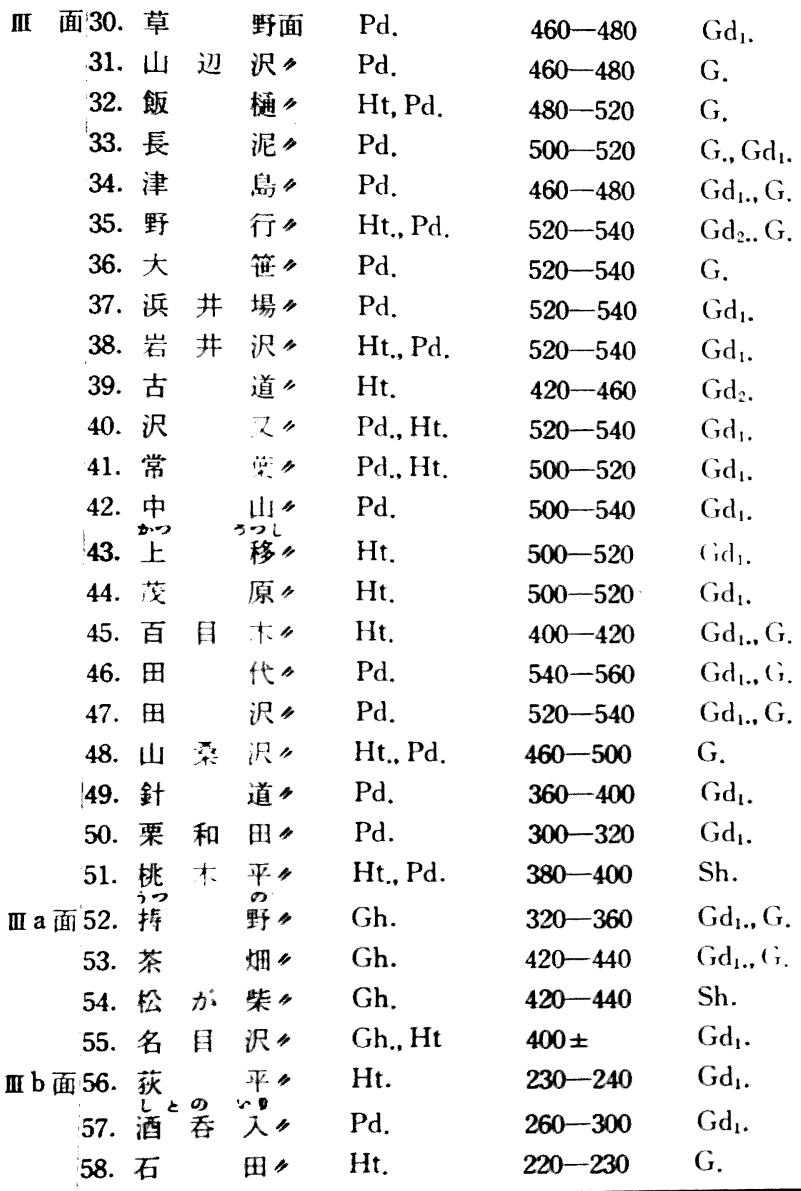

古道川では 15 20kmにあり，大き な相漟がある。これは前者の場合, 各流路の途中に，河流の下刻に対す る抵抗の大きい古生，中生層が分布 しているため, 要急点の後退があ まり上流部まで進まず，しかも明膫 な形をとつているのに対し，後者の 地域は花茥岩類から成り, 遷急点の 啳迠が速かで，比校的上流部まで達 しており，形が若下不明になつてい るためである。これより上流にも， 新田川, 落尾川, 古滇川では Knick Point $(560 \sim 600 \mathrm{~m})$ がありここれら はII面の中に代い、迄んでおり，II 面 とIII 面との境界を示すものと考党 られる。

宇多川, 新田川の上流部は, 広瀬川 右岸のいくつかの支流によつて截颔 された形を示しているが(Fig-8), こ れは広瀬川の支流の方が下位の侵玲 基準面からの流路が短いために，透 总点がすでに分水界まで澾したり， 堎所によつては土平洋㑬の流域にま で谷顓が食い込んで来ている(川促 東方水境附近）ことを示すものであ 万5。

位置, 形態

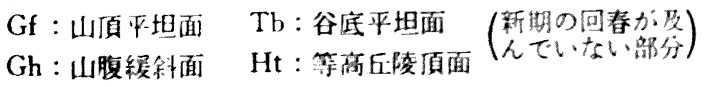

Pd : 山管平坦面

岩斦

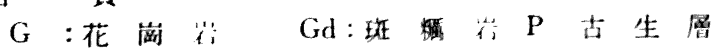

$\mathrm{Gd}_{1}$ : 古期花厥閃緑岩 $\mathrm{Ag}$ : 集 塊 岩 $\mathrm{M}$ 中生層

$\mathrm{Gd}_{2}$ : 新期 ” $\mathrm{Sh}:$ 結晶片莸

析の進み方により種々な起伏昌が，ある規則珄 をもつて生ずるものと思われ，これを吟味すれ ば，地形発洋の一面を把握することができるで あろ5。

(b) 河床絿断面灾明 ${ }^{(20)}$ は河床綎断曲線に 現れる顕算なKnick pointを対比して,阿武险高

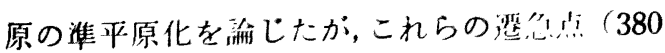
$\sim 500 \mathrm{~m}$ ) 位直は, 東縁の柴浩線から, 宁多川, 真野川，新田川では約 $10 \mathrm{~km}$, 室原川, 葛尾川,
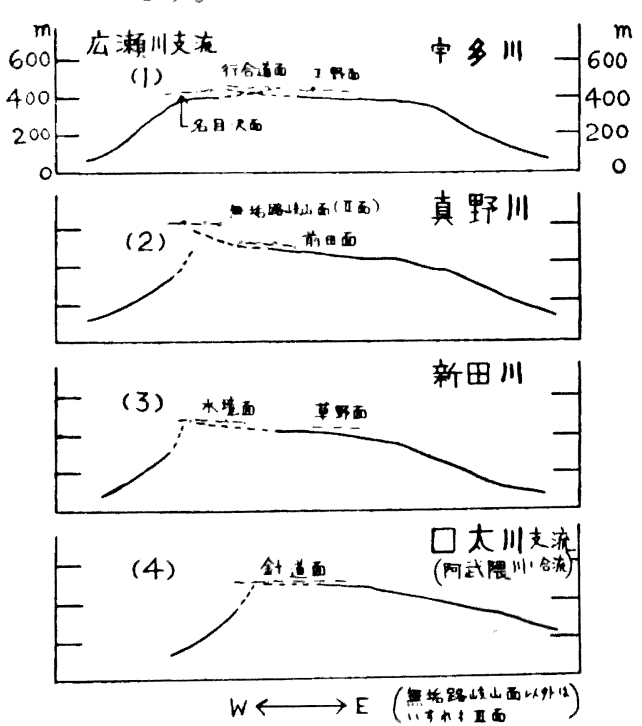

Fig 8. 河床縦断面に见られる上流激

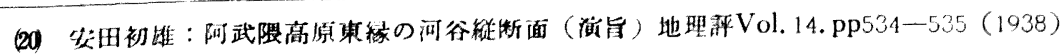


(c) 河谷留断面各河川について近似の汹 床活度の 4 地点（1. 流部，500 -600m (21)，中流部 400～500m 及び300４00m, 下流部 $100 〜 200 \mathrm{~m}$ ) に扮汁る雀断面を作り，これを浮度別にまとめ て図示したものがFig-6である。これから次の こ上がらが判る。

(1)上流部の模断助はよく開いた Muldental 乃平 Flachmuldental の形を示す。I 面下媩の斜 面が concave にII 面に移つていること，及び

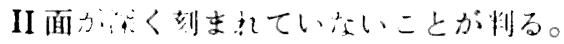

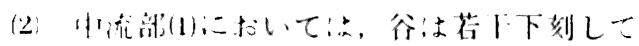

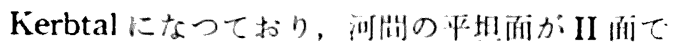

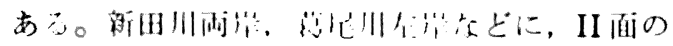

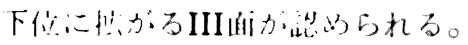

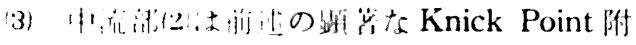
近久はての下话域に尚り，II，III面は现在の流

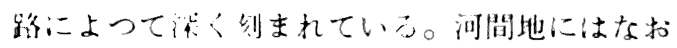
II 面が㕕く残されている。

(4) 下流部では䦥析が更に進んでおり，III而

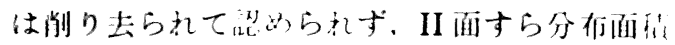
を堿じている。

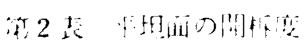

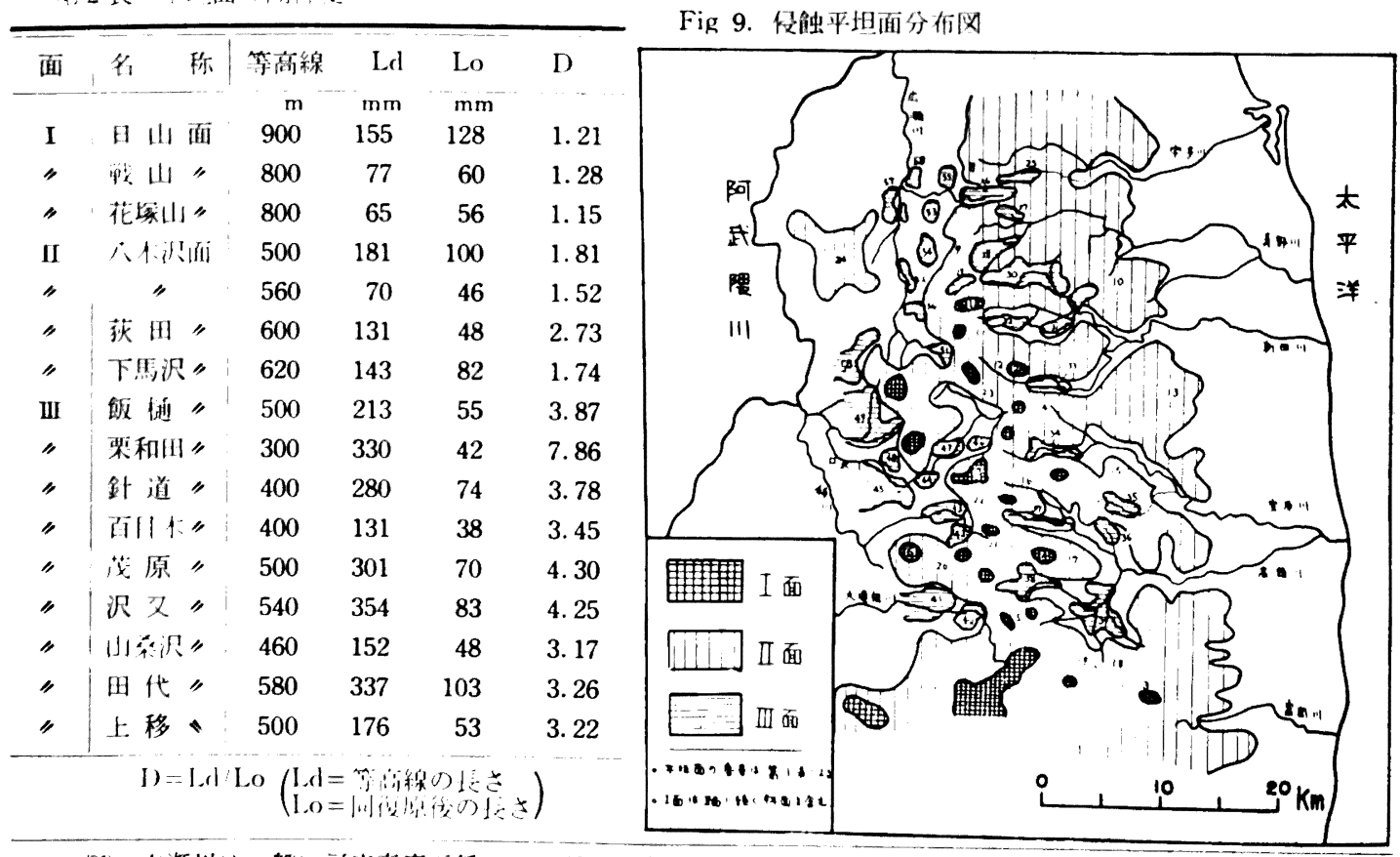

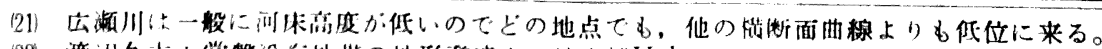

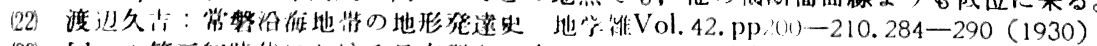

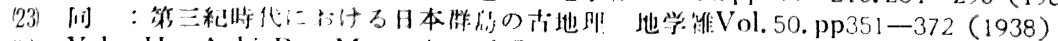

24 Yabe, H. : Aoki, R. : Mesozoic and Cenozoic IVistory of the Abukuma Plateau and its Foreland along the Pacific Coast. Jap. Jour. Geol. Geogr. Vol. 3. pp $23-37$ (1924)
(5) 阿武隈河谷側の杪断面は各地点とも類似 した形を示す。これは，各流路の長さが短かく 構造線に沿つていたり（広瀬川），一㥞な岩質の 上を流れていたりする（口ふ川以南）ため, 遷 急焦の後退が速かに行われ，上，下流で横断面 が岁しく異るような束情がなかつたためである 5 。

(c) 平坦面の開析度:

ここでは简単のため，開析度を次の傎によつ て示す。即ち，ある面を示等高線の一部の長 さ Ldを测定し, 行を埋める方法で順次原面を復 元して㐆後に行られた同じ激分の長さLoを求め $\mathrm{D}=\mathrm{Lo} / \mathrm{Ld}$ てねわ。この維果が第 2 表である が，I 而の佔の小竹ことは前逨の事实に一致し， III 面の值が大圤二とは, 現在の侵玲基準面への 闌析が萑しいことを示している。特に栗和田面 に法，阿武隈川から多くの小河川が刻及込んで 米ているので，閐析が密しく進んでいる。

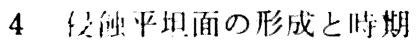

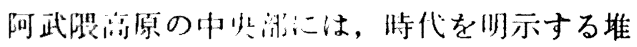
程層がないので, 従米から準平原化の時代につ

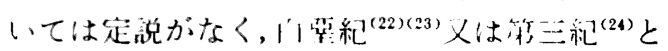

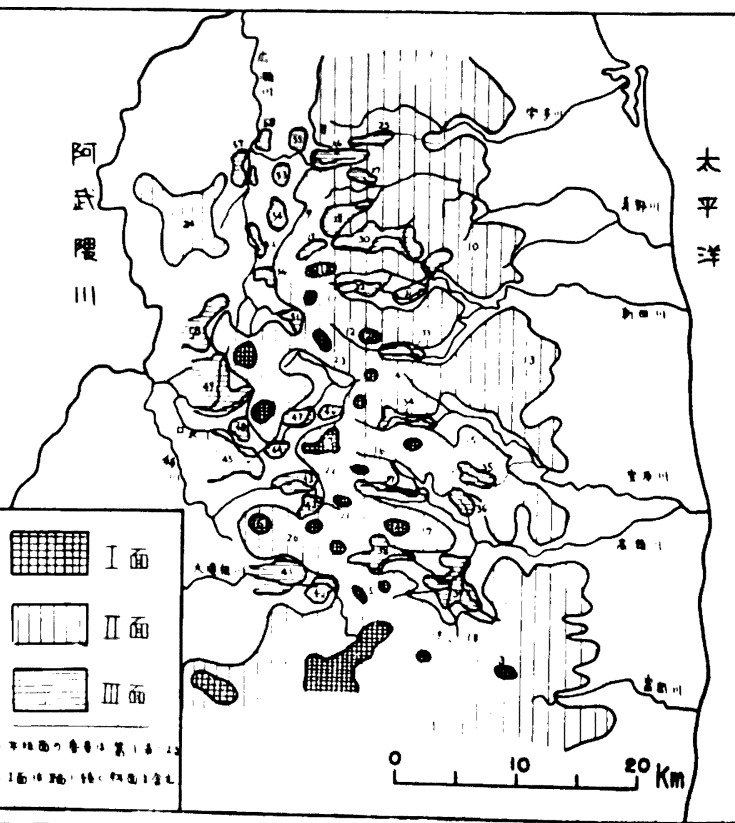


としか記載されていなかつた。しかし，北部に 分布する霊山層群は，植物化石により中部中新 珫とされているから ${ }^{(25)}$ ，これが被覆堆積してい る II 面は,少くとも中新世中期以前に形成され たことが知られる。このことと常磐炭田を含む 阿武德山地束縁の沿岸地域の地質構造とを考放 合わせると，次のことがらが判る。即ち，川地

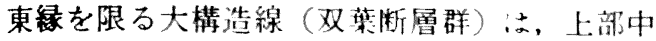
新統多賀層群堆皘直前及びその彷も引続いて, この地域全体にわたつて同一時期に活動したこ とが知られている(26)。地質图(27)によれば，陉二 その内側 $8 \mathrm{~km}$ 附近にここれと平行な断層線があ

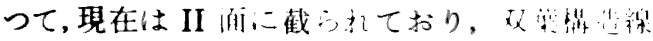
のような明瞭な地形的境界といなつていない。

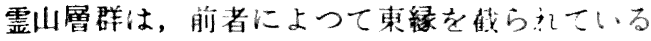
が，後者を覆つている。即ち，この古期の断燐 線は II面形成前に活動したものでちことが判 る。

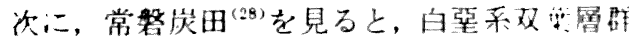
を不整合に覆つて籍三采が厚く分倠している。

下部から，漱新統内制署群，下部中新統测上行 層群，上部中新統多贺屏群，下部鮮新統竜の口

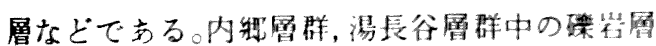

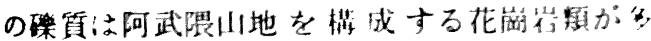
い。これらの各屏群間には著しい斜交又は平行 不整合面があり，陸上での削制が長く続いたこ とを物語つている。徒つて，それらの闑，何武

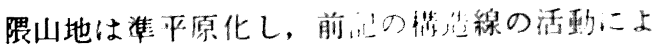
り間歇的に隆起しなが的，隆起準平原となつた のであろう。また, 現在浻岸地带に立く発涬す る100-160mの斥陵は所々段丘堆積物をうすく のせるが明らか洰侵触面であつて，多贺層群及 び竜の口層を㵶つているから，鮮新世中期以降 削剝の続いた時期があつ的ことが判る。この传 触面と, 阿武隈川地内のIII醇とは直接つながつ ているところがないので断䛅できいが，同時 期に生成されたものであつて, 鮮新让: 未期の双

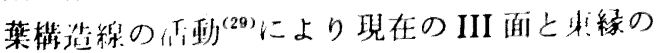

丘陵面とに分離したのではないかと思われる。 しかしこれらの侵蝕面が同一封期のものと確 定できるか否かは今後の課題である。

以上のことから，本地域の地形発澾を考える と Fig-10の上万になる。I面はわずかに川頂及

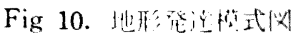

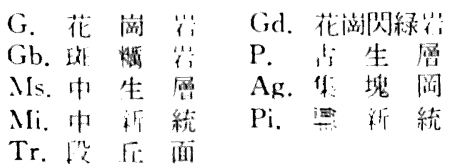

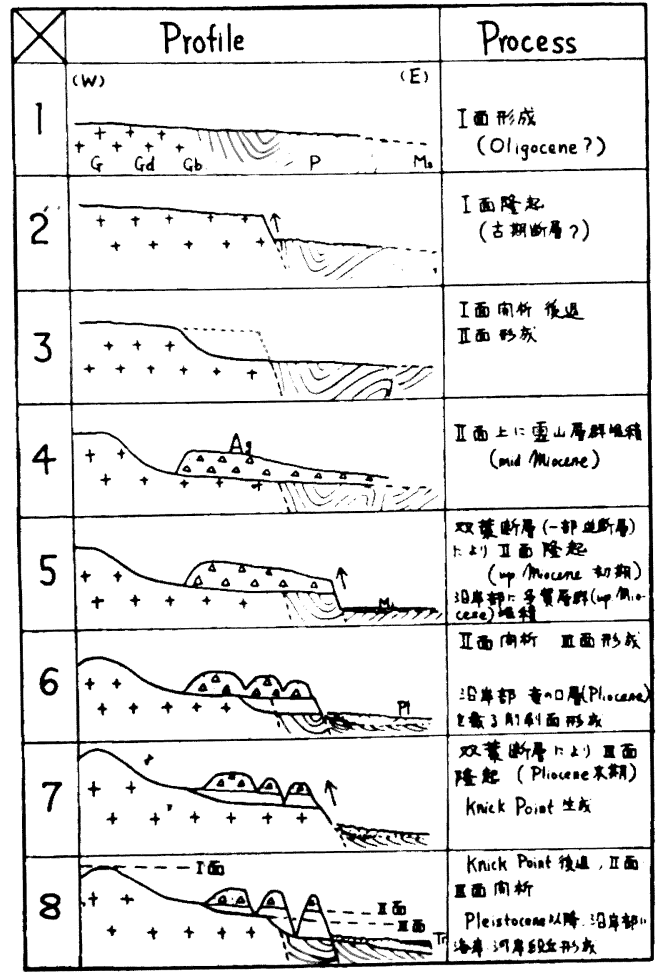

ぴ川頑からのぴている尼根としてあるた゚けで， け存されている面们当小さいので,これだけか らこの面の生成機楼を知ること沈相難である。 しかし，少くともII 解よりは明らかに古い时代 の侵蚛面としでかなり広く笼立していたこと が考えられる。II 面は，I面隆起（古期断層線 による?)後これ哬折して生成された。II

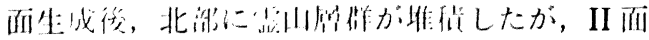


はこの附近で，海面からわずかの高さにあつた らしい(霊川北辺に中新統下部の浅海性堆皘層 がある)。中新世後期に人ると,東縁の双菓構篮 線が活動した。霊山層群はこれによつて截られ ているから、この断層連動と, II 面を隆起させ た理動とは同一のものではなかつたかと思小れ

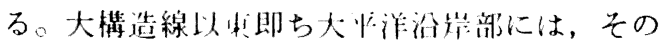
後鮮新統竟の口層が推积したがこれが陵化与 る前後に, 前述の最後の隆起渾的（断層又は暁 曲）が起り，III面が垷在の位置に米たのであろ 5 。

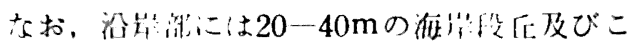
机に絖く河等段斥か，例之ば空原川では60-80 $\mathrm{m}$, 熊川, 活岡川で80-100mに分们するが, これらの段丘面は阿武㗄儿地内潘には入つてい ない(30)。しかしこれらの河川の $150 \mathrm{~m}$ 附近に Knick Pointがありここれが技丘面の上流部への 姃长之一政するからこのKnick Pointは, 前述 の軿著な Knick Point とは全く異つた新しいも のである。

阿武隈河谷侧には，東縁におけるような明胉 な蓝:浩的境界はないが，II 面の分布は大体去瀬 川, 口斤川の東側であり，その西縁に III 面が报 がつている。広瀬川流域の III 面がIII a III b に分けられることは, この地域のみがIII面形成 の際に2问の隆起渾㙑を行つたことを示すもの でる。

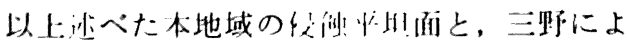

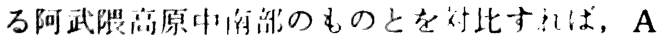

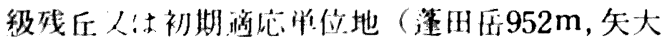
卧山965mなど）が面に，BＤ級残丘入は中

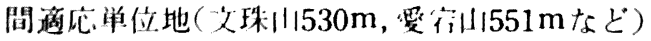

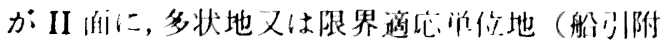
沂，小野新町附近）がIII面に各々一攱する。船 引附近の $400 \mathrm{~m}$ 前後の等高丘陵面は, 常整面, 百目不面(III西)に連繶する平坦面である。
5 絬 語

（1）阿武郎高原北部には, I-, II-, III面の 3つ の侵玲平坦面群が、別され，III面の一部を除き いずれも隆起準平原面を示している。

(2) I 面 $(800-100 \mathrm{~m})$ は, 高原上に点在す る山峰に原面を残寸他，斜面後退により原面が 消尖したものも，ほほ等高の尖峰として認めら れる。いずれもII 面を基準面とする残丘であ る。

3） II 面 $(560-660 \mathrm{~m})$ は, I 面の周辺に広

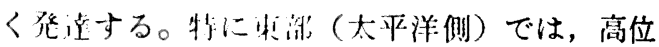
の透急点 $(560-600 \mathrm{~m})$ の後退が及んだ地域に おいては, 河間丘陵, 尼根などの平頂部であり これの及ばない地域ではな扮谷底に保存されて いる（此时，梨ノ木平など）。

(4) III 面 $(540-300 \mathrm{~m})$ は太平洋側では II 面 を刻む玨要河川に㳂つて分布するか，その面皘 は河閌地の II 面よりも一般に狭い。阿武涱河谷 侧では, 西方に広く発達し, 縁辺準平原 (marginal peneplain）の形態を示す。しかし，広瀬 川流域のみは III 面が III a，IIIbの上下 2 段に 分かれ，特異な形を示している。

(5) 準平原の生成時代は, II 面が中新世中頃 （需川層群堆积前）までに形成され，双葉構造 線の做動で隆起したものと考光られる。従つて I 面はそれ以前またIII面は鮮新比以降生した ものと茀えられる。

(6)降起の結果, 各河川に明暸なKnick Point

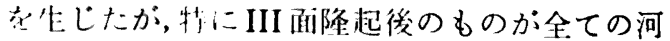
川に柋められる。このKnick Pointの下流では,

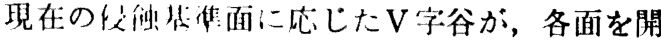
析しているがそそょり上流部では，谷は厷く 阙いた前輸题の形態を示し，侵蝕面はよく保存 されている。

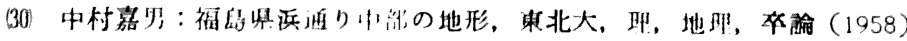




\section{Geomorphological Development of the Northern Part of the Abukuma Plateau.}

\section{Yoshio Nakamura}

It has been hitherto known that on the Abukuma Plateau, which are composed mainly of old granite and grano-diorite intruded in Paleo-and Mesozoic Era, there are two different levels of uplifted peneplains. These are both revealed by the summit level derived from the topographical maps. Besides these, however, the writer has recognized, by field observations and other methods, the third level of erosion surfaces which develop as pediment or hill-foot surface along the major valleys running through the upper surfaces. Therefore, the uplifted peneplains in this region are distinguished from each other as follows, each of them showing its formation in sequence in different ages.

Level-I (upper surface) : Mountain crests, $800-1,000 \mathrm{~m}$ in height, scattered on the whole area.

Level-II (middle surface): Hill tops or ridge-crests, $560-660 \mathrm{~m}$ in height, surrounding the upper surface more wide by spreading in the eastern part of the region.

Level-III (lower surface): Flat erosion surfaces along the hill foot or valley side, $300-540 \mathrm{~m}$ in height:especially in the western part shown as a marginal peneplain.

There is a geological evidence about Mt. Ryozen that indicates the completion of middle surface belongs to later Miocene. Judging from the longitudinal profiles of valley floors, recent base level has no influence on this region higher than $400 \mathrm{~m}$ ) but the results of past changing of erosion base levels are clearly recognized in the relief energy difference between the center and the margin of this region.

\section{Geomorphological Development around Iwate Volcano Yutaka Mizuno}

The author has made a survey of the volcanic mudflow areas and river terraces around Iwate volcano. The results gained are as follows :

1. There are 4 volcanic mudflow areas of various size around Iwate volcano; respectively Koiwai, Aoyamacho, Takizawa and Tairadate.

2. The river terraces; Shizukuishi and Iwamachi terraces are in the Shizukuishi basin; Koma and Makibori in the Tairadate basin:Ueda and Kawamata along the Kitakami river.

3. The Shizukuishi and Koma terraces are lake deposits temporarily accumulated in the waters dammed up by Koiwai and Takizawa mudflows.

4. The higher terraces in each area (the surfaces of the Shizukuishi, Koma and Ueda terraces) are covered with a volcanic sand layer of $10-15 \mathrm{~cm}$ in thickness, named Iwate Volcano $\mathrm{C}$ group.

5. The Shizukuishi terrace can be correlated with the Ueda and Koma terraces respectively, and the Iwamochi terraces to the Kawamata and Makibori ones. 